Research Article

Maciej Franz*

\title{
Stanislaviv in the face of the Polish-Soviet War 1939 Polish Garrison - Soviet Garrison
}

https://10.1515/openms-2020-0107

Received Oct 07, 2020; accepted Dec 11, 2020

\begin{abstract}
In 1921-1939 Stanyslaviv was one the bigger polish garrisons. The approach of the war the reason for leaving the town by polish troops. In September of 1939 the garrison in Stanyslaviv was rather small, consisting of small logistic units. Until now the historians have been interested in the face of this particular garrison in those few September days of 1939th. This is an attempt to showcase the most important events that happened while the polish troops were stationed in town and were still trying to provide peace and safety it and its people.
\end{abstract}

Keywords: Polish troops, polish campaign, 1939, Second World War

The Polish campaign of 1939, as the first episode of World War II, was not the same in all parts of Poland. For the inhabitants of Stanislaviv and a significant part of the Stanislaviv Voivodeship, it did not turn out to be a war against the Third Reich, but Soviet aggression - it is another episode on the long list of PolishRussian armed conflicts in history.

For people who lived in the western, southern and northern provinces of the Second Polish Republic, the war immediately took on a normal appearance. Air raids by enemy planes began, as a result - bombing, and a few days later the front was changed. The symbols of those days were mass groups of soldiers moving through these territories, both Polish soldiers who had to defend their homeland and those Germans who sought to conquer the Polish state.

Initially, the war was hardly felt for the inhabitants of the eastern or south-eastern provinces. There were radio broadcasts, announcements, the press reported more; unfortunately, most of it was bad news, but the war was not yet noticeable. The fighting took place far from their homes. This situation also applied to the Stanislaviv Province and Stanislaviv. An exception in this regard was the appearance of German bombers in the area of the city, which focused their activities mainly on the bombing of military facilities outside the city'.

At the beginning of the war, the Polish army suddenly left the city. The Stanislaviv garrison was not small in the interwar period, so the quick departure from the city by such a large number of military units had to be noticeable in the city. Moreover, Stanislaviv was closely related to the history of the Polish Army through the battle of Krechowce on July 24, 1917 and later the traditions of the First Krechowce Uhlan Regiment ${ }^{2}$. The role and importance of the army for the life of the city was determined not only by memory and tradition, but primarily by the strategic importance of the railway lines that cross through this voivodeship towards Romania, and since 1939 also the emergence of the border with Hungary. Stanislaviv, as the second largest garrison of the Polish Army in the VI Corps District Command (CDC) after Lviv, had to function in symbiosis with the army.

1 B. Prugar-Ketling, Aby dochować wierności. Wspomnienia z działań 11. Karpackiej Dywizji Piechoty. Wrzesień 1939, Warszawa 1990, s. 120.

2 B. Kost, Stanisławów. Z życia miasta, Iwano-Frankiwsk 2017, s. 171-176.

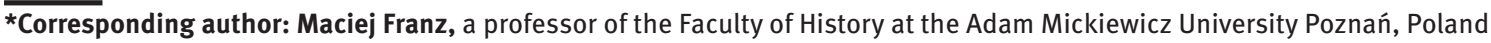


In the city were located the headquarters and staff of the 11th Infantry Division, the command, staff and chiefs of all services of the Podolska Cavalry Brigade, 48th Infantry Regiment, 6th Uhlan Regiment, the main part of the 11th Light Artillery Regiment, 6th Horse Artillery Squadron and many smaller units ${ }^{3}$. For many years, it seemed that the army was one of the most important elements of the city's functioning. The command of the Stanislaviv garrisons was not yet one of the institutions of the Polish state in the city. The Polish Army played too important a role in the south-eastern voivodeships of the Second Polish Republic. The last commander of this garrison was Colonel Bronisław Prugar Ketling, who assumed the position on August 14, 1939, based on the decree of the President of the Second Polish Republic of August $5^{4}$. In this position he replaced Brigadier General Kazimierz Lukowski, who on August 12 left the post of commander of the "Jaslo" section'. For the new commander, the Stanislaviv garrison was not an unknown place, because from October 1938 he was the commander of the 11th Infantry Division ${ }^{6}$. He had time to get to know the city itself, its specificity, including nationality. He got to know all the most important people in the city's life relatively quickly.

In the city were a lot of dislocated military units, and as a result no major celebrations could take place in Stanislaviv without the participation of the Polish Army. A particularly ceremonial celebration took place on May 3, 1939, during which the Lviv Merchants' Association donated six heavy machine guns, purchased at its own expense to strengthen the potential of the Polish Army in the city? Subsequently such transfers of military equipment in the city took place in the following weeks, on the initiative of other circles, which also collected funds to strengthen the Polish army. It was a time of great dedication of the city's inhabitants ${ }^{8}$. However, this was accompanied by a marked increase in anxiety. It was also a consequence of the withdrawal from the garrison of some units. The official propaganda of the Polish state built the image of a «strong, compact and ready» Poland, but the feelings were different. From the spring of 1939, during successive stages of increasing the level of readiness and then mobilizing the Polish army, new units disappeared from the city 9

Especially noticeable in this regard was the process of mobilization, and then the departure from the garrison of units of the 11th Infantry Regiment, because basically this unit was mobilized as part of the first roll of general mobilization ${ }^{10}$. This meant that the subunits of the 48th Infantry Regiment and the 11th Light Artillery Regiment left the city ${ }^{11}$. Basically, it was planned to use railway lines, which were to allow the fastest possible relocation of the 11th Infantry Division, which, under "Plan Z", was to constitute the reserve of the "Karpaty" Army, commanded by General Kazimierz Fabrycy, together with the 45th Reserve Infantry Division and the 10th Cavalry Brigade. For units from Stanislaviv, the area of Olkusz was planned as a zone of their concentration ${ }^{12}$.The process was not without problems, which was due to the insufficient capacity of the railway lines, the growing activity of German aviation, attempts to paralyze all Polish fighting in the rear, and, unfortunately, the growing chaos, which was to become stronger day by day. It is true that in those first days of September, there were no open protests by various groups of people against the units of the Polish Army in the Stanislaviv voivodeship, but later they often had to firing for «making» free passage. Unfortunately, the lack of success on the front, together with the persistently national and

3 P. Pulik, Województwo stanisławowskie w 1939 roku (do wybuchu II wojny światowej), [w:] Stanisławów i Ziemia Stanisławowska w II Rzeczypospolitej. Wojskowość - Bezpieczeństwo - Społeczeństwo - Kultura, red. nauk. M. Kardas, A.A. Ostanek, P. Semków, Warszawa -Stanisławów 2017, s. 172.

4 Centralne Archiwum Wojskowe, sygn. CAW_I.313.11.13, k. 99, Rozkaz nr 10/39.

5 Centralne Archiwum Wojskowe, sygn. CAW_I.313.11.13, k. 98, Rozkaz nr 9/39.

6 Centralne Archiwum Wojskowe, sygn. CAW_I.315.18.47, Zarządzenie Ministra Spraw Wojskowych, BPres. L. 2740/tjn. IV-1 z 24 października 1938 roku.

7 A. A. Ostanek, W stużbie ojczyzny. Wojsko Polskie w systemie bezpieczeństwa województw pohudniowo-wschodnich II Rzeczypospolitej (1921-1939), Warszawa 2019, s. 431.

8 Ibid, s.433.

9 Dokładnie temat mobilizacji oddziałów wojskowych na terenie VI DOK przedstawił A.A. Ostanek, Przebieg mobilizacji 1939 roku na terenie Okręgu Korpusu nr VI „Lwów”, „Studia z dziejów wojskowości”, t. II, Białystok 2013, s. 205-238.

10 The exceptions were the 2nd Battalion of the 49th Infantry Regiment and units of the 11th Light Artillery Regiment, which were mobilized as part of the 2nd list of general mobilization.

11 R. Rybka, K. Stepan, Najlepsza broń. Plan mobilizacyjny „W” i jego ewolucja, Warszawa 2010, s. 99, 101, 105.

12 Polskie Siły Zbrojne w drugiej wojnie światowej, t. 1, Kampania wrześniowa 1939, cz. 1, Polityczne i wojskowe położenie Polski przed wojna, Londyn 1951, s. 259. 
reluctant environment of the Ukrainian population, brought more and more problems for the Polish Army. In Stanislaviv itself, such events did not take place in the first days of September $1939^{13}$.

The above-mentioned process of mobilization and concentration of the 11th Infantry Division took place between September 1 and 4, 1939. The commander of the unit, together with his staff, set off to the front on September 2 in the evening from the Chryplin station, located near Stanislaviv. He was not to return to the city, which was his last pre-war garrison.

There are no memories of the departure of the last regular military units from Stanislaviv, although it can be assumed that the atmosphere was similar to the one that accompanied this event, for example in the Kolyma: "It was late in the evening and they walked in fours, in helmets and denim uniforms, with backpacks

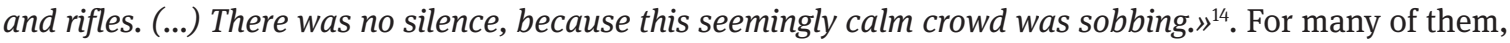
these were their last minutes in these areas.

Apart from the units stationed in the city during the interwar period, Stanislaviv also became an important element in the creation of the Carpathian Half-Brigade of National Defence from mid-1937 $7^{15}$. His command was under the command of the 11th Infantry Regiment, and one of the four battalions was called «Stanislaviv», which strongly associated it with the city, the more so as the unit carrying out its mobilization was the 48th Infantry Regiment, stationed, of course, in Stanislaviv. However, when the war broke out, this unit was no longer in the city, despite the fact that it was not intended to be used on the front, but rather planned as units to defend the front lines ${ }^{16}$. After all, these soldiers fought in the Battalion Węgry of the Karpaty Army, so they did not have the opportunity to defend the city with which they were, however, clearly associated.

After leaving the city, actually before September 1, regular units of the Polish Army, which had their assignments under Plan « $\mathrm{Z}$ » and were directed to the front, remained in the city, and the Stanislaviv garrison was not eliminated. It continued to play a significant role in the plans of the Polish command, especially given that the railway ran through the voivodeship, including the city, to Romania ${ }^{17}$. As a result, the liquidation of the garrison could not be allowed. The second serious circumstance was the mood among the local population, which was observed for months. While the population of the Jewish nationality, which dominated in the city, stood firm and unequivocally in favor of loyalty to Poland, especially in the face of the threat of an attack by the Third Reich, the mood of the Ukrainian nationality was completely different. A few months before the war, the State Police observed increasing nationalism and hostility towards Poland, but there was no unrest in the city. In this situation, it would be irresponsible to leave the issue of security in the city and its vicinity only on the shoulders of the State Police. Thus, the preservation of the military garrison in Stanislaviv in September 1939 was a necessity and the only rational decision.

Initially, Major Franciszek Jarzębiński was reinstated in military service as the commander of the war garrison in Stanislavivi ${ }^{18}$. He performed this function from September 1 to September 8,

13 W. Włodarkiewicz, Przed zagłada. Społeczeństwo Wolynia i Małopolski Wschodniej wobec państwa polskiego (1935-1939), Warszawa 2013, s. 509-511.

14 A. A. Ostanek, Garnizon Kołomyja w latach 1919-1939, [w:] Kołomyja, Pokucie i Huculszczyzna w II Rzeczypospolitej. Wybrane zagadnienia, red. nauk. A.A. Ostanek, A. Smoliński, Warszawa 2017, s. 131.

15 P. Pulik, Województwo stanisławowskie w 1939 roku (do wybuchu II wojny światowej)..., s. 173.

16 Zarys dziejów wojskowości polskiej w latach 1864-1939, pod red. P. Staweckiego, Warszawa 1990, s. 721.

17 P. Pulik, Województwo stanisławowskie w 1939 roku (do wybuchu II wojny światowej)..., s. 174.

18 He was born on August 9, 1895 in Stary Sącz, he probably died during the World War II, unfortunately, the circumstances of his death are not clear. He served in the Austro-Hungarian Army during the First World War, where he was promoted to the rank of officer. Member of the Military Organization of Poland, since 1918 he has been fighting in the defense of Lviv. He defended the city against Ukrainian troops, commanding in the rank of lieutenant a sub-section of the right sector of "Bem". Admitted as a lieutenant to the Polish Army. He served in the 38th Infantry Regiment. He took part in the Polish-Bolshevik war. After the end of war, he was appointed a non-commissioned officer to the 48th Infantry Regiment. Eventually, he joined the Poviat replenishment commands in Lviv and served there until the second half of the 1930s. In 1939 he was mobilized again. He managed to leave the country. He was interned in Târgoviște, Romania. At the beginning of 1940, he went with other Polish soldiers from Budapest to Kaisersteinbruch (Stalag XVII A1). Unfortunately, all certain news about him ends here. He was awarded the Silver Cross medal of War Order of Virtuti Militari, the Order of the Cross of Independence and three times the Cross of Valor. 
1939 ${ }^{19}$. From September 9, command of the garrison was taken over by Colonel Tadeusz Kurnatowski, who initially, as part of mobilization, became the commander of the «Stanislaviv» Cavalry Reserve Center. He was to remain the second and last war commander of the garrison in Stanislaviv.

The first command of the new commander regulated the situation in the garrison, especially in the context of radical changes in the distribution of units, and also conditioned the performance of the duties of the remaining army in the city ${ }^{20}$. The preserved document also makes it possible to clearly define the tasks assigned to the soldiers of the Stanislaviv garrison. These included: maintaining peace and security in the city, recording and taking over all mechanical means of transport remaining in the city, especially in industrial plants, organizing talks on air defense, or enabling public access to radio broadcasts. Until 9 September, virtually no new aspects of the activity of the city commandant, and thus probably of the garrison itself, appeared. The war was increasingly present in the lives of the inhabitants, although it was very far from the city and the soldiers.

The garrison was based on parts that were rear, logistical and aimed to provide support to the front units. The garrison included the Guard Battalion No. 64, whose commander was the retired lieutenant colonel of infantry Władysław Tobiasiewicz ${ }^{21}$. It was the largest and strongest unit stationed in the city in September 1939, but even it did not have heavy weapons, and most of what fell into the hands of the soldiers were of French origin and from the First World War.

Beside to this battalion, as part of the war garrison, there was a Reserve Regiments of Cavalry, Reserve center of railway engineers No. 1, the National Platoon of the Gendarmerie, Assistant Company No. 66, the Storages of Intendant Material, Bakery, the Construction Authority and several other smaller logistic units, mainly responsible for material needs in the city, subordinated to the Polish army before the war.

As can be seen, on the basis of these units, it was impossible to build any defense of the city, and in no way such tasks were set for the Stanislaviv garrison ${ }^{22}$.

Relatively little is known about the composition of units in Stanislaviv in the first two weeks of September. Unfortunately, only few documents have survived in this regard. For example, apart from the commander of the unit, it is possible to define only one soldier in the Guard Battalion No. 64. The gunner Stanisław Adamczyk was certainly serving in it $^{23}$. This knowledge, however, is the result of searching for information provided by families, and not as a result of researching sources. In this respect, the war turned out to be ruthless, causing real havoc in the source material.

19 He was born on October 16, 1887 and died in 1940 while interned in Hungary. In 1914 he joined to the 1st Uhlans Regiment of the Polish Legions. There he was promoted to the rank of Platoon-leader. In July 1917, he joined to the Polish Armed Forces. However, he did not go to the front, but go to school, where he had to prepare for military service. After the war he was accepted into the Polish army. As a captain, he participated in the Polish-Bolshevik war in the ranks of the 7th Uhlan Regiment. He remained there until 1924, when he was transferred to the 2nd Cavalry Division. In 1927 he was promoted to the rank of major. A year later he was transferred to the 5th Cavalry Regiment. The next promotion to the rank of Lieutenant Colonel took place in 1929, and to the rank of Colonel - in 1935. From January 15, 1936 to March 31, 1938 he was the commander of 17th Regiment of Greater Poland Lancers in Leszno, and then, from February 1, 1938 to August 1, 1939, he was the commander of the 18th Pomeranian Uhlan Regiment in Grudziądz. The beginning of the war threw him to Stanislaviv, where after the arrival of the Soviet army he managed to break into Hungary and was interned there. He was awarded the Silver Cross medal of War Order of Virtuti Militari, the Order of the Cross of Independence and the Cross of Valor.

20 Rozkaz dzienny $n r 65$ z 1 września 1939, CAW, sygn. I.372.52.40, k. 160-161.

21 He was born on March 20 or June 20, 1886, and died in the spring of 1940, shot by Soviet soldiers, his name appears in the "Ukrainian Katyn list”. He served in the First World War in the Austro-Hungarian Army, reaching the rank of officer. Enlisted in the Polish army in 1919, he took part in the Polish-Bolshevik war. In 1920 he received the rank of major. In the 1920s he served in the 48th Infantry Regiment in Stanislaviv. In 1929 he was briefly transferred to the poviat replenishment commands in Kielce, and six months later he returned to Stanislaviv, to the post of commander of the poviat replenishment commands. He was remobilized in September 1939. He was taken prisoner by Soviet soldiers, which eventually led to his execution, as were several thousand other Polish officers. During his military service he was awarded the Cross of Valor.

22 However, it was to play an important role in relation to the operational plans for the so-called Romanian Bridgehead. For example, it was planned to send weapons from military depots in Tarnopol, W. Włodarkiewicz, Przedmoście Rumuńskie 1939, Warszawa 2012, s. 91-92.

23 It was one of four Guards battalions formed on the basis of CDC VI. Next to it were also: CDC VI: Guards Battalion № 61 in Lviv, № 62 in Lviv and № 63 in Stryi. 
From September 9, the new commander of the Stanislaviv garrison was to continue the previous activities of the commandant's office. However, the first preserved document signed by the new commander shows the devastation taking place in the functioning of the army in the city: the actual «mobilization» of all Stanislaviv doctors, counteracting the declining state of discipline in military units, or emerging acts of sabotage. Unfortunately, this became a kind of «everyday life» during the war in the garrison of Stanislaviv ${ }^{24}$.

It is difficult to clearly define what «everyday life» looked like in the Stanislaviv garrison. There are no memories and no correspondence between command and higher level commands. In fact, the source material ends with the outbreak of war in this respect. One can only assume that the basic problem for the garrisons' command was information chaos and the lack of relevant information that would show the real situation on the front. As a result, uncertainty and rumors had to play their part. In addition, the situation was aggravated by the fact that no large military units withdrew to the city during the fighting in September 1939. The city was not on the route of the withdrawal of the Polish Army to the so-called "Romanian Bridgehead”. On September 14, the commander of the 11th Infantry Regiment, General B. Prugar-Ketling, decided to reduce the rolling stock of his unit to a minimum and send all unnecessary elements of it under the command of Captain Grzegorz Romaszkan from Stanislaviv to Rudki ${ }^{25}$. However, in view of the events of September 17 and the entry of the Red Army troops into the borders of the Polish state, as well as their rapid progress into the interior of the country, it was not possible to carry out this order. There is no evidence that the trains of the 11th Infantry Regiment managed to reach Stanislaviv, even in part, before it was captured by the enemy troops.

Meanwhile, units of the 21st Armored Battalion, commanded by Major Jerzy Lutsky, appeared near the city on September 17 at about 3:00 a.m. However, the unit retreated and was not going to enter the city. It probably did not even try to contact with the garrison team.

Stanislaviv did not survive the arrival of a defeated or fleeing Polish army, which escaped from enemy forces. It has always been a traumatic event for the city's residents. At the same time, this meant the absence of any real news, except for those that were broadcast on the radio. It is difficult to judge exactly when the communication system collapsed, but it remains well known that it was one of the greatest weaknesses of the Polish Army during the Polish campaign of 1939.

The outbreak of the war with the Soviet Union was a tragedy for the state, which was in a very difficult position. The whole concept of the withdrawal of Polish Army units to the so-called Romanian Bridgehead has become obsolete. Units of the Ukrainian Front under the command of 1st Rank Commander S.K. Tymoshenko headed in the direction of Smolensk. Directly responsible for the attack on Stanislaviv was the 12th Army, whose units operated in the southern section of the Polish-Soviet front. Unfortunately, the resistance of the Polish army was small from the very beginning.

Information about the Soviet Union's breach of the non-aggression pact probably reached the garrison command in Stanislaviv, most likely by radio. However, there is no doubt that the rapid progress of Soviet troops could not be kept as a secret for the officers in Stanislaviv. They knew perfectly well the state of their own forces and on this basis were able to determine what the defense potential of the Polish army on the eastern border might look like. The location of Stanislaviv, in the immediate vicinity of the pre-war PolishSoviet border, had to contribute to taking immediate steps. Despite the lack of appropriate source materials, it can be assumed that on Monday, September 18, 1939, the major part of the Polish military in Stanislaviv was no longer there. Eventually, the Polish army left the city. Most of the units previously located there had to move towards the borders of Romania or Hungary to avoid being seized by the rapidly advancing Soviet troops, but also by German troops coming from the west.

At that time, Soviet units were already approaching Stanislaviv. The operation was carried out by units that were part of the 13th Rifle Corps. Soviet troops acted as if they expected serious resistance. The 99th Rifle Division attacked the northeastern part of the city, and the 72nd Rifle Division attacked the south ${ }^{26}$. Serious support for the Soviet air force, which did not operate over the city, was not expected, due to the

24 Rozkaz dzienny nr 68 z 9 września 1939, CAW, sygn. I.372.52.40, k. 160-161.

25 R. Dalecki, Armia „Karpaty”1939, Warszawa 1979, s. 277.

26 W. Włodarkiewicz, Przedmoście rumuńskie..., s. 142. 
lack of any activity of Polish combat aircraft at that time. Similarly, most of the artillery units were directed to the Lviv direction ${ }^{27}$.

The Soviet troops did not meet resistance and entered Stanislaviv without a fight. Immediately, they were directed further west to cut the withdrawal routes towards the Romanian border for Polish troops. The history of a new, this time Soviet, garrison began in the city.

For the inhabitants of the city, the departure of the Polish Army and, consequently, its loss meant the real end of the current world. This is perfectly illustrated by the words of Tadeusz Olszański: «Today I know exactly that on September 17th everything collapsed and Polish independence ended, and the Red Army entered Stanislaviv three days later. ${ }^{28}$.

Stanislaviv was occupied by the Soviet army on September 19, 1939. On September 19, 1939, German troops also entered the area of Stanislaviv County. They were greeted with ovations by the local Ukrainian population, for whom this was the end of Polish rule and attempts to assimilate them with Poland. Many Ukrainian nationalists hoped for the possibility of the emergence of even a Ukrainian state, which turned out to be quite close to the reality of the time and a complete lack of knowledge about the Third Reich .

After three days, the German troops withdrew beyond the border line established in accordance with the Ribbentrop-Molotov Agreement, and the area of the Stanislaviv Province, including the city, was occupied by the Soviet army. This was also greeted with ovation by the same Ukrainian population, and also this time by the Jewish population. A new order began with the capture of the city by new "owners". The Soviet authorities gave the local people the so-called three days of freedom, during which they did not actually react to any acts of "revolutionary justice" imposed by the local Ukrainian population against the Poles who remained in the city. According to later reports, post-war arrests were made at the time, often with the participation of the People's Commissariat for Internal Affairs (NKVD) ${ }^{29}$. The captured Poles were kept and starved in inhuman overcrowded and unheated prisons, persecuted, blackmailed and forced to testify, beaten and tortured. Prisoners were often killed without a single sentence. How much this was the scenario of the first three days of Stanislaviv under the new rule, and how much the memory of the long presence of Soviet power, it is difficult to assess unequivocally today.

These violent outbreaks did not affect most officials of the voivodship or the pastoral old age. Together with their families, they managed to leave the city in time and eventually crossed the Hungarian border at the Yablunytsia Pass ${ }^{30}$.

These memoirs also underscore the fact that the self-proclaimed Ukrainian police, consisting of local people in civilian clothes, with red armbands and rifles on their strings, were a special terror for the Polish inhabitants. They disarmed and killed the captured soldiers of the Polish arm, who, often in small groups or individually, tried to get to the Romanian or Hungarian border and the police officers. More active Poles were caught and killed. As for the soldiers of the Polish army, we can assume that these events did not take place in Stanislaviv, but in the city district.

Polish soldiers captured by the Soviet army were held in the village of Dolynka near Stanislaviv. The conditions there were terrible, as one of the inhabitants of Włodzimierz Bogucki recalled years later: "As a scout, in September 1939, I brought water and food to officers who were imprisoned in Dolinka near Stanislaviv. It was hot and they were being fed salty herring. They begged for a drop of water. With my friends, we carried them food and threw it over the fence. Then a Red Army soldier shot at me and shot my jacket. Polish soldiers were not detained in the city, especially when in the Stanislaviv began the Sovietization."”1.

Ukrainians who had previously served in the Polish Army also returned to the city. Initially, it was a spontaneous process, but after the conclusion of appropriate agreements by the Soviet Union with the Third

27 W. S. Milbach, Artyleria Krasnoj Armii w pochode w Zapadnoj Ukrainie i Zapadnoj Białorusiju w 1939 roku, „WojennoIstoriczeskij Żurnal”, nr 9, 2014, s. 47.

28 B. Kost, Stanisławów. Z życia miasta..., s. 223.

29 At that time, there was a bad reputation about the prison on Bilinsky Street. From it, practically all Poles went only deep into the USSR.

30 W. Włodarkiewicz, Przedmoście rumuńskie..., s. 157.

31 D. Chajewski, Ach ta woda w Stanisławowie. Wszystko było inne. https://plus.gazetalubuska.pl/ach-ta-woda-w-stanislawowiewszystko-bylo-inne/ar/11690402 (dostęp 26.08.2019) 
Reich, it became formalized ${ }^{32}$. This was not a safe social element for the new Soviet government, so it was not decided to include them in the new urban structures. Moreover, from the very beginning this process was very much controlled by the NKVD authorities ${ }^{33}$. Documents from the beginning of November 1939 leave no doubt that this institution quickly gained a decisive voice in the city. Both the newly created civilian and military structures had to take into account the decisions of the NKVD, and subsequent decisions issued by officers of the department, which controlled not only the situation in the city but also in the region.

The first structures of the Soviet civil authorities as well as the military garrison officially appeared on September 20. This was the result of the decision of the Soviet Army. It was established a temporary civil administration, headed by Vasylyi Chuchukalo. A temporary city council was also established, including L. Tarasovskyi, S. Cherovniak, D. Shtunder. M. Tyuleniev became the military commander of the city ${ }^{34}$. They officially represented the Soviet authorities in the first days after the capture of the city. However, everything was controlled by the Moscow authorities. They were responsible for creating branches of the so-called "Workers' guards", directed employees to the city, and above all, heads of newly created the police departments, passport services, etc. These new structures of Soviet power took over the former buildings of the Polish State Police, the Polish Army, and voivodeship or poviat offices.

Soviet troops appeared in the city, but the emergence of the NKVD was much more important. They were crucial in the first weeks and months of the Soviet occupation. For the NKVD officers within the established structures in Stanislaviv, the most important thing was the destruction of all structures of the Polish armed underground. In some available documents of that period one can find information that in Stanislaviv their number was about 30-40 people ${ }^{35}$. However, these reports would be certainly exaggerated, and the amount of possible Polish military underground in Stanislaviv was insignificant ${ }^{36}$. The city survived the process of Sovietization very quickly, and successive waves of repression against the Polish population through organized transport to the Soviet Union only accelerated this process.

The process of Sovietization affected not only the Polish population, but also the Ukrainian population, who after a few days quickly noticed that the new Soviet government was determined not only to eliminate all Polish national life, but also to declare war on all forms of Ukrainian nationalism. As one of the Ukrainian historians wrote in exile: "From September 1939 to June 1941, Stanislaviv and Stanislavivschyna existed under the Soviet occupation. Ukrainians lived sterilized in the "greatest democracy", Moscow. The imperialist system, that was in addition to terror, to control of material requirement, provocation, was not known to the population until then. With the arrival of the Bolsheviks, all manifestations of Ukrainian and national life died out. Some of the most nationally active people were lucky to have saved themselves by escaping abroad, getting to the west, while the rest were either killed or arrested and deported to the east by the Bolsheviks, and some were "sterilized.". However, under the conditions of Soviet terror, the secret organization of Ukrainian Nationalists (OUN) continued to operate in the west of Ukrainian lands. "37. As a result, the problem for the new Soviet garrison was not only the Poles who had won the war, but also the Ukrainians, who were once again disappointed in their national hopes.

Until June 1941, Stanislaviv became a city of Soviet Ukraine ${ }^{38}$. At that time, the city lost its Polish character, and subsequent aggressions and occupations also led to further losses and destruction. Those difficult days in September 1939 changed the history of this city forever, although it was only one of the episodes of the Polish-Russian wars.

32 Patrz, M. Litwin, Niemiecko-radziecka wojenna kampanija 1939 w Haliczini. Nowe rosyjski dokumenty, bmw. 33 НКВД-МВД СССР в борьбе с бандитизмом и вооруженным националистическим подпольем на Западной Украине, в Западной Белоруссии и Прибалтике (1939-1956), Составители: И. М. Владимирцев, А. И. Кокурин, Москва 2008 , s. 25. 34 Украӥнський Національно-Визвольний Рух на Прикарпатті в ХХ столітті. Документи і матеріали, том 2, Книга 1 (1939-1945), відповідальний редактор Микола Кугутяк, Івано-Франківськ 2009, s. 18.

35 A. A. Zdanowicz, Zachodnij pochod NKWD, „Wojenno-Istoriczeskij Żurnał”, nr 6, 2011, s. 49.

36 However, the Soviet authorities managed to arrest part of the former Polish elite of Stanislaviv Voivodeship, as well as those outside the Polish state, for example an officer of the 2nd Division of the General Staff of Rafal Brandzel, Український НаціональноВизвольний Рух на Прикарпатті в ХХ столітті. Документи і матеріали, том 2, Книга 1 (1939-1945)..., s. $21-22$.

37 К. П. Українська влада у Станиславові 1941 року, [w:] Almanac of the Stanyslaviv Region, edited by Bohdan Krawciw, t. 1, New York - Toronto - Munich 1975, s. 150.

38 Formalna decyzja zapadła 1 listopada 1939 roku, Sbornik zakonov SSSR i ukazov prezidijma Wierhownogo Sovieta SSSR (1938 - ijul1956), Moskva 1956, s. 21. 


\section{Bibliography}

\section{Archival sources}

Military Historical Bureau, Central Military Archives in Warsaw (CAW)

Command files 11. Infantry Division - sygn. CAW_I.313.11

Department of Armaments - sygn. CAW_I.315.18.47

Headquarters of the Stanislaviv Garrison - sygn. CAW_I.372.52

State Archive of Ivano-Frankivsk Oblast (DAIFO)

Voivodeship Office in Stanislaviv - sygn. 2, opis 13, nr 750, nr 768, nr 769, nr 775, nr 785.

Published sources:

НКВД-МВДСССРвборьбесбандитизмомивооруженнымнационалистическимподпольемна Западной Украине, в Западной Белоруссии и Прибалтике (1939-1956), Составители: И. М. Владимирцев, А. И. Кокурин, Москва 2008.

Реанімовані Історією. Івано-Франківська Область, Упорядник, автор передмови Лук'ян Вардзарук, Івано-Франківськ 2004.

Sbornik zakonov SSSR i ukazov prezidijma Wierhownogo Sovieta SSSR (1938 - juli 1956), Moskva 1956.

Украйнський Національно-Визвольний Рух на Прикарпатті в ХХ столітті. Документи і матеріали, том 2, Книга 1 (1939-1945), відповідальний редактор Микола Кугутяк, Івано-Франківськ 2009.

\section{Research paper}

Almanac of the Stanyslaviv Region, edited by Bohdan Krawciw, t. 1-2, New York - Toronto - Munich 1975.

Bezpieczeństwo Wewnętrzne Województwa Stanisławowskiego w 1939 roku w sprawozdaniach wojewody, Wybór źródeł, wstęp i opracowanie naukowe Rafał Roguski, Wojciech Włodarkiewicz, Paweł Pulik, Siedlce 2016.

Dalecki R., Armia „Karpaty” 1939, Warszawa 1979.

Komar Wołodymyr, Miasto Stanisławów pod sowiecką i niemiecka okupacją, „Scripta Historia”, nr 21, 2005, s. 187-195.

Kost Beata, Stanisławów. Z życia miasta, Iwano-Frankiwsk 2017.

Litwin Mykoła, Niemiecko-radziecka wojenna kampanjia 1939 w Haliczini. Nowe rosyjski dokumenty, bmw.

Milbach W. S., Artyleria Krasnoj Armii w pochode w Zapadnoj Ukrainie i Zapadnoj Białorusiju w 1939 roku, „Wojenno-Istoriczeskij Żurnal”, nr 9, 2014, s. 45-49.

Obrona Lwowa. 1-22 listopada 1918. T. 2. Źródła do dziejów walk o Lwów i województwa poludniowowschodnie 1918-1920, pod red. J. Waniorek, Warszawa 1991.

Ostanek A.A., W stużbie ojczyzny. Wojsko Polskie w systemie bezpieczeństwa województw poludniowowschodnich II Rzeczypospolitej (1921-1939), Warszawa 2019.

Ostanek A.A., Jak świętować to tylko z żotnierzami... Udział wojska w najważniejszych uroczystościach międzywojennego Stanisławowa (1919-1939), [w:] Po stronie pamięci i dialogu... Stanisławów i Ziemia Stanisławowska w dobie przemian społecznych i narodowościowych XIX i pierwszej połowy XX wieku. Polityka - Wojskowość, red. nauk. Mariusz Kardas, A.A. Ostanek, P. Semków, t. 1, Warszawa-Stanisławów 2017, s. 255-284.

Ostanek A.A., Przebieg mobilizacji 1939 roku na terenie Okręgu Korpusu nr VI „Lwów”, „Studia z dziejów wojskowości”, t. II, Białystok 2013, s. 205-238.

Ostanek A.A., Garnizon Kołomyja w latach 1919-1939, [w:] Kołomyja, Pokucie i Huculszczyzna w II Rzeczypospolitej. Wybrane zagadnienia, red. nauk. A.A. Ostanek, A. Smoliński, Warszawa 2017, s. 97-137.

Polskie Sity Zbrojne w drugiej wojnie światowej, t. 1, Kampania wrześniowa 1939, cz. 1, Polityczne i wojskowe położenie Polski przed wojna, Londyn 1951.

Prugar-Ketling Bronisław, Aby dochować wierności. Wspomnienia z działań 11. Karpackiej Dywizji Piechoty. Wrzesień 1939, Warszawa 1990.

Pulik Paweł, Województwo stanisławowskiew1939 roku (do wybuchu II wojny światowej), [w:] Stanisławów i Ziemia Stanisławowska w II Rzeczypospolitej. Wojskowość - Bezpieczeństwo - Społeczeństwo - Kultura, red. nauk. M. Kardas, A.A. Ostanek, P. Semków, Warszawa -Stanisławów 2017, s. 163-176. 
Rybka R., Stepan K., Najlepsza broń. Plan mobilizacyjny „W” i jego ewolucja, Warszawa 2010.

Seńczyszyn Hubert, Generat dywizji Bronisław Prugar-Ketling. Biografia wojskowa, Rzeszów 2019, rozprawa doktorska, rękopis w posiadaniu Autora.

Smolinnski Aleksander, Proweniencja i tradycje formacji Wojska Polskiego garnizonu Stanisławów w latach 1921-1939, [w:] Po stronie pamięci i dialogu... Stanisławów i Ziemia Stanisławowska w dobie przemian społecznych i narodowościowych XIX i pierwszej połowy XX wieku. Polityka - Wojskowość, red. nauk. Mariusz Kardas, A.A. Ostanek, P. Semków, t. 1, Warszawa-Stanisławów 2017, s. 208-254,

Smoliński Aleksander, Wybitni oficerowie kawalerii z garnizonu Stanisławów z lat 1921-1939. Przyczynek do dziejów kresowych formacji jazdy Wojska Polskiego II Rzeczypospolitej, [w:] Wobliczu nowej rzeczywistości. Stanisławów i Ziemia Stanisławowska w latach 1918-1923, t. 1, red. nauk. M. Kardas, A.A. Ostanek, P. Semków, Warszawa-Iwano-Frankiwsk 2018, s. 206-257.

Włodarkiewicz Wojciech, Przedmoście rumuńskie 1939, Warszawa 2012.

Włodarkiewicz Wojciech, Przed zagładą. Społeczeństwo Wotynia i Małopolski Wschodniej wobec państwa polskiego (1935-1939), Warszawa 2013.

Włodarkiewicz Wojciech, Postawy Polaków, Ukraińców i Żydów -Mieszkańców Województwa Stanisławowskiego Do agresji Niemiec i ZSRR w 1939 roku, „Україна: культурна спадщина, національна свідомість, державність”, nr 17/2008, s. 364-383.

Włodarkiewicz Wojciech, Województwo stanisławowskie w przededniu wybuchu II wojny światowej oraz w czasie kampanii polskiej 1939 r., [w:] Si vis pacem, para bellum. Bezpieczeństwo a polityka Polski. Księga Jubileuszowa ofiarowana profesorowi Tadeuszowi Dubickiemu, red. Robert Majzner, CzęstochowaWłocławek 2013, s. 541-556.

Zarys dziejów wojskowości polskiej w latach 1864-1939, pod red. P. Staweckiego, Warszawa 1990.

Zdanowicz A. A., Zachodnij pochod NKWD, „Wojenno-Istoriczeskij Żurnał”, nr 6, 2011, s. 47-53.

\section{Internet resources}

https://pl.wikipedia.org/wiki/Władysław_Tobiasiewicz (dostęp 26.08.2019)

https://pl.wikipedia.org/wiki/Tadeusz_Kurnatowski (dostęp 26.08.2019)

https://pl.wikipedia.org/wiki/Franciszek_Jarzębiński (dostęp 26.08.2019)

Chajewski Dariusz, Ach ta woda w Stanistawowie. Wszystko było inne. https://plus.gazetalubuska.pl/ach-tawoda-w-stanislawowie-wszystko-bylo-inne/ar/11690402 (dostęp 26.08.2019) 